\title{
THE PROBLEM OF BAD POPES: THE ARGUMENT FROM CONSPICUOUS CORRUPTION
}

\author{
JERRY L. WALLS* \\ Houston Baptist University
}

\begin{abstract}
The fact that a number of popes have been bad in the sense that they did not even meet minimal standards of moral integrity and sincere piety poses a serious problem for Roman Catholicism. After surveying a gallery of these infamous popes, I hone in more exactly on just what the problem is. I then argue that the problem remains on both a weak providence view and a strong providence view. According to the former, there is no guarantee that the man chosen pope is God's will. According to the latter, deploying the resources of middle knowledge, God can make sure that popes infallibly avoid error and teach only truth by making sure the right man is chosen pope. Neither view satisfactorily explains how the papacy can be as important as Rome says it is while so many popes have been such unworthy holders of the office.
\end{abstract}

KEYWORDS: infallibility, conspicuous corruption, Duffy, Ratzinger, Flint

There have been many good popes as well as some truly outstanding ones. Gregory the Great was not called that for no reason, and more recently pope John Paul II was widely and deservedly admired and loved by Christians all over the world, Protestants as well as Roman Catholics. This is as it should be. Given the critical role the pope serves in the Roman Catholic church, one would expect that popes would not only be persons of exemplary Christian character and reputation, but also men gifted with outstanding theological understanding, spiritual maturity and practical leadership skill. This is the sort of profile for any bishop in the New Testament (1 Timothy 3:1-7), so anyone chosen to be the bishop of bishops, the Vicar of Christ, the Supreme Pastor, the Chief Shepherd of the Church should certainly be expected to fit this profile.

As anyone with even a casual knowledge of church history knows, however, the expectation of consistently good popes is shattered by the brutal truth that many popes fell far short of the New Testament qualifications for

* JERRY L. WALLS (PhD 1989, University of Notre Dame) is Research Professor at Houston Baptist University. Email: jwalls@hbu.edu. 
bishops. And it is not a story of predominantly good or excellent popes with only a handful of bad actors that slipped through, but rather, there have been quite a few popes who not only fell short of the New Testament profile, but were notorious scoundrels.

These bad popes are an embarrassment to Roman Catholics, but they are often dismissed as irrelevant to the claims of Rome. They have no evidential significance when assessing the claims of Rome, we are told. I want to argue otherwise. To get a preliminary idea of what I have in mind, consider a similar argument from the opposite direction, namely, the argument from 'conspicuous sanctity'. This is a classic argument for Christianity that appeals to reality of the notable saints Christianity has produced. The fact that persons who have embraced Christ and his gospel have often been morally transformed is suggestive evidence for the power and truth of Christ and the gospel. Indeed, if Christianity is true, we should expect such sanctity to be exhibited. Of course, such evidence is hardly sufficient to establish the truth of Christianity by itself, but the fact that conspicuous sanctity is exhibited is one piece of evidence for Christianity. In a parallel way, I want to suggest that bad popes provide material to construct an argument from 'conspicuous corruption' against the claims of Rome.

To get a better idea of what I mean, let us consider some concrete cases of papal mischief. More specifically, I want to consider several characteristic cases of popes behaving badly. This material is common knowledge among historians, but these particular snapshots are drawn from Eamon Duffy's authoritative work tellingly titled Saints and Sinners: A History of the Popes. It is worth noting that Duffy, a distinguished Roman Catholic historian, was a member of the Pontifical Historical Commission. Before sharing these snapshots, it is important to emphasize that many of these stories cannot be fully understood without taking into account the broader historical and political factors influencing the papacy at the time. Indeed, the context of many of these cases is a power struggle between popes and emperors and kings over whose authority was greatest. Readers who want the larger story are encouraged to read Duffy's book.

After our quick stroll through the gallery of bad popes, I shall state more precisely just what is the problem raised by these notorious bishops of Rome. Then I shall consider and assess two different strategies to account for bad popes, and argue that both of them face serious difficulties. As we shall see, there are a number of parallels between the problem of bad popes and the more general problem that evil poses for theism.

\section{A Gallery of Impious Popes and Dubious Politics}

Snapshot One: A Son of a pope versus another pope. Let us begin with Vigilius (537-555), a classic case of a pope whose unbridled ambition drove 
him to seek the papacy, and whose story is filled with characteristic political intrigue. We begin our story with the death of pope Agapitus whose papacy lasted only one year (535-536). Vigilius immediately set to work to get himself appointed pope by currying the favor of the wife of the Emperor of Constantinople, a sexually adventurous woman who wielded considerable power. At this time, orthodox Chalcedonian Christology was controversial in the east, and was not favored by the Emperor's wife, so Vigilius assured her that he would repudiate Chalcedonian Christology. Taking bags of money for a bribe, he rushed to Rome with the dead body of pope Agapitus, anxious to claim the papacy for himself. But alas, he was too late, for when he got to Rome, a king who was a rival to the Emperor had already appointed a new pope, namely Silverius (536-537), who was the son of another previous pope, Hormisdas (514-523). Undeterred however, and determined to achieve his goal, he managed to trump up false charges against Silverius, and got him demoted and banished. With his rival out of the picture, Vigilius was finally elected pope. But the power struggle was not over. A bishop in the town where Silverius was banished took up his defense, and persuaded the Emperor to bring him back for a fair trial. But again Vigilius triumphed, and had Silverius arrested and banished again, this time to an island, where he died of malnutrition. Summing up this rather convoluted tale, Duffy writes: 'To all intents and purposes, one pope, and he the son of a pope, had been deposed and murdered by another' (Duffy 2014: 55).

Snapshot Two: Matronly Mafioso Maneuvers. For hundreds of years, the pope had not only vied for power with the Roman Emperor, but had also formed an uneasy alliance with him and been protected by him. When the Roman empire was dissolved, the papacy was left vulnerable. It was not a pretty picture, as Duffy explains.

Deprived of the support of the empire, the papacy became the possession of the great Roman families, a ticket to local dominance for which men were prepared to rape, murder and steal. A third of the popes elected between 872 and 1012 died in suspicious circumstances-John VIII (872-82) bludgeoned to death by his own entourage, Stephen VI (896-7), strangled, Leo V (903) murdered by his successor Sergius III (904-11), John X (914-28) suffocated, Stephan VIII (93942) horribly mutilated (Duffy 2014: 103-104).

John $\mathrm{X}$ was one of the few popes who tried to resist aristocratic domination, but he was murdered by the Theophylacts, the powerful family who been his patrons in getting him appointed pope. Duffy fills in the details as follows.

The key figure in both John X's appointment and his deposition was the notorious Theophylact matron, Marozia. She also appointed Leo VI (928) and Ste- 
phen VII (928-31), and she had been the mistress of Pope Sergius III, by whom she bore an illegitimate son whom she eventually appointed as Pope John XI (931-936) (Duffy 2014: 104).

Snapshot Three: Is this kid old enough to be pope? Marozia's son, Alberic II was the secular ruler of Rome and appointed a number of popes, some of whom were at least decent. His legacy as pope maker is mixed however, as Duffy explains, because he persuaded the clergy and nobility to make his own son Octavian pope when Agapitus II (946-955) died. 'Octavian was duly elected Pope John XII (955-64) at the ripe age of eighteen. He was to die at the age of twenty-seven, allegedly from a stroke while in bed with a married woman' (Duffy 2014: 105).

Snapshot Four: A meteoric rise. Pope John XIX (1024-32) perhaps wins the prize for the most rapid rise to the top. 'He was a typical representative of his age. He had bribed his way to the papacy, and had been elevated from the status of layman to pope in a single day' (Duffy 2014: 108).

Snapshot Five: A bewildering number of ways to become pope. The current practice of electing a new pope by the College of Cardinals goes back to the year 1059 when it was decreed that the seven cardinal bishops should choose the pope. This was controversial at first, and the rules remained murky for some time. The number of cardinals who elect the pope has increased over the years. 'Popes in the past had been appointed in a bewildering variety of ways - elected by assemblies of clergy and people, hailed by acclamation at the funerals of their predecessors, nominated by local gangbosses, appointed by emperors' (Duffy 2014: 118).

Snapshot Six: Spiritual weapons for political ends. 'From Innocent IV onwards many of the popes forfeited moral credibility by using some of the most solemn spiritual weapons of the reform papacy for purposes which were blatantly political. Innocent, for example, preached 'crusade' against Frederick and his successors, and Martin IV (1281-5) and Honorius IV (1285-7) supported as a 'crusade' what was blatantly a dynastic war waged by France against the kingdom of Aragon... In the hands of these lesser men the lofty spiritual claims of Gregory VII and Innocent III came increasingly to look like a cloak for cynical political manipulation' (Duffy 2014: 156).

Snapshot Seven: A pope in hell. Boniface VIII (1294-1303) achieved a certain literary distinction by being one of the popes that Dante consigned to hell in his monumental poem, The Divine Comedy. Boniface was a complex figure who was accused by his critics not only of sodomy, but of being a rank unbeliever who even denied the resurrection. With more than a little irony, Duffy observes: 'But whatever Boniface did or did not believe about God, sex, or the afterlife, he believed passionately in the papacy' (Duffy 2014: 161). Believing in the papacy meant believing in supreme papal power, 
which included power over kings and earthly rulers. King Philip of France was not willing to accede to these claims, and had plans of his own to extend the range of his empire. 'Boniface was having none of this, and in 1302 he issued the bull Unum Sanctam, the culminating blow in a propaganda war against the French crown. In it the pope notoriously claimed that it is altogether necessary for salvation for every human creature to be subject to the Roman pontiff' (Duffy 2014: 162).

Snapshot Eight: How many popes? One, two, or three? It is a complicated story, but one of the most infamous episodes in the history of the papacy is what is called 'the great schism'. We can begin the story with the fact that for several reasons, mostly political, the papacy was located for seventy years in Avignon, France. As yet another example that the popes very much reflected regional interests, all the popes during this period were French. The last of these, pope Gregory XI (1370-8) returned to Rome, the historic seat of the papacy. When he died, there was fear that the cardinals, many of whom were now French, would elect another French pope. The citizens in Rome loudly protested this idea, and the cardinals, fearing their wrath, elected an Italian, pope Urban VI (1378-89). Unfortunately, he turned out to be violent, domineering and paranoid. In less than six months, the cardinals who had elected him declared his election invalid, and fled Rome and elected another pope, namely, Clement VII. Clement then returned to Avignon with the cardinals who had elected him, while Urban appointed twenty-nine new cardinals, from all across Europe. 'There were now two popes, two papal administrations, two self-contained legal systems. The countries of Europe would have to choose which Pope they would obey' (Duffy 2014: 168).

Cardinals from both sides recognized this to be a problem, and in 1409 , a council at Pisa attempted to resolve the matter. They deposed both the Roman pope and the Avignon pope, and elected a new pope, Alexander V (1409-10). The two popes who were deposed rejected the authority of the council, so there were now three men who claimed to be pope. The matter was finally resolved later by the Council of Constance. So, who was really pope during the great schism?

Even saints were confused about the rights and wrongs of the situation. St Catherine of Siena supported Urban. St Vincent Ferrar supported Clement. Nations tended to choose their allegiance along dynastic and political lines... The popes excommunicated each other and placed their rivals supporters under interdict.

In the long perspective of history, the Roman Catholic Church has accepted that the 'real' popes were Urban and his successors elected by his cardinals and their successors. At the time, however, and throughout the thirty-nine years during which the schism persisted, this sort of clarity was hard to come by. Certainly there is no getting around Urban's near insanity, and his brutal treatment of op- 
ponents-at one point he had six cardinals under torture, five of whom eventually simply disappeared (Duffy 2014: 168-169).

Snapshot Nine: Renaissance Rakes. Renaissance popes are among the most colorful and infamous. Patrons of the arts, they typically lived lavish and extravagant lifestyles. Pope Sixtus IV (1471-84), for instance, spent 100,000 ducats on his coronation tiara, 'more than a third of the papacy's annual income' (Duffy 2014: 185). The most notorious of these Renaissance popes was Roderigo Borgia, who became Alexander VI (1492-1503). He fathered at least nine illegitimate children, one of whom, Cesare, was the model who inspired Machiavelli's political classic, The Prince. 'Magnetically attractive to women, he had a succession of mistresses with whom he lived quite openly, the last and youngest these, Giulia Farnese, even after he became pope, in his sixties' (Duffy 2014: 189).

Snapshot Ten: A barely teenage cardinal grows up to be pope. Innocent VIII (1484-92) 'having married his son into the Medici family, obligingly made Lorenzo the Magnificent's son Giovanni a cardinal-at the age of thirteen... this Cardinal Medici would be elected Pope Leo X... When in 1517 Leo X discovered a plot against him among the cardinals, he executed the ringleader and swamped the Sacred College by creating thirty-one new cardinals in a single day' (Duffy 2014: 191-192).

\section{Refining the Problem}

This gallery could be extended considerably, but these ten snapshots are enough to raise the issue I want to discuss. In short, how do we explain the actual history of the papacy with all of its raw ambition, scandal and sordid corruption? Were all these man chosen by God to occupy the office of pope? What, if anything, does Providence have to do with choosing the popes? One might think a great deal, given the singular importance of the papacy according to Rome. Consider these lines from Vatican I, from the First dogmatic constitution on the Church of Christ. It was this document that formally defined and affirmed the doctrine of papal infallibility in 1870 . After stating that the papacy was founded by Christ for the permanent benefit of the Church, the document goes on to make the following claims.

Therefore, whoever succeeds to the chair of Peter obtains by the institution of Christ himself, the primacy of Peter over the whole Church. So, what the truth has ordained stands firm, and blessed Peter perseveres in the rock-like strength he was granted, and does not abandon that guidance of the Church which he once received.

For this reason, it has always been necessary for every Church-that is to say the faithful throughout the word-to be in agreement with the Roman Church because of its more effective leadership (Vatican One 1869-1870: session 4, chapter 2). 
Notice, Peter's 'rock-like strength' is said to reside in his successors, and to empower succeeding popes to guide the Church. And this is why all faithful Christians should be in agreement with Rome, 'because of its more effective leadership'.

Now then, consider this conditional statement. Given the strong claims Rome makes about the pope, one might find it to be very probable.

(P): If (A) Peter was indeed given authority over the whole Church, if his successors, the bishops of Rome, have the same authority; if God has providentially preserved an unbroken succession from Peter to the present; if the pope is the Supreme pastor of the Church, the Vicar of Christ, and he has the singular role of preserving the church from error and preserving unity; then $(\mathrm{B})$ it is reasonable to expect that all popes would meet the basic New Testament standard for bishops, or at the very least be persons of sincere faith in Christ, and basic moral integrity.

I emphasize that this is a very minimal standard. If the New Testament criteria for bishops is too high a standard for the bishop who has jurisdiction over all bishops, then perhaps the less stringent standards for deacons might be expected (1 Timothy 3:8-13). The standard is not perfection. These persons might have various flaws and blind spots, and weaknesses. They might have some embarrassing sins in their past. But still, a sincere faith in Christ and the gospel, and some discernible evidence of sanctification should be expected.

The sad truth, of course, is that several of the popes have not lived up to even these modest expectations. And this poses a problem for anyone who is inclined to judge this conditional statement to be true. That is, if one is inclined to think (B) is highly probable given (A), then the fact that $(\mathrm{B})$ is not true makes A) highly improbable. Roman Catholics have little option but to deny $(\mathrm{P})$. That is, since $(\mathrm{A})$ is essential to their faith, they will want to deny that $(\mathrm{B})$ is highly probable, given (A). (For a more formal version of this argument, see Collins and Walls 2017: 251-255.)

It might be objected that even such modest standards should not expected if we consider a biblical example, namely the actual history of the kings of Israel and Judah. While some of those kings were godly men who led with integrity, many others fell far short of this ideal. Moreover, consider that some of the authors of the Bible, such as Moses and David committed murder. In light of this history, we should hardly be surprised at the unsavory history of the papacy.

While this objection might have a certain initial plausibility, it is not convincing for a couple of reasons. First, the Old Testament monarchy was instituted at least partly due to a rejection of God as King, and a concession to Israel's preference for an earthly king so they could be like other nations. A 
major lesson to be learned from the story is the inevitable failure that results when God's leadership is rejected. The bigger lesson yet is our need for Christ, David's greater Son.

Second, the Old Testament monarchy was a genetic dynasty, in contrast to the papacy, which is a charismatically chosen succession of bishops. Again, the Roman claim is that God has providentially assured an unbroken succession beginning with Peter, to the present. God, through the Holy Spirit, directed the choice of the popes. So, the better comparison is not between the Old Testament kings and the papacy, but between the Old Testament prophets and the papacy. When we consider the Old Testament prophets, all of them who are recognized as true prophets were indeed men of basic moral integrity and genuine love for God, even prophets like Jonah, who were less than perfect in reflecting God's love and grace. If all the prophets that God called were men of integrity and true faith, it hardly seems too much to think all of the 'chief shepherds' of the Church would meet the modest standards of our conditional statement. The papacy, after all has the advantages not only of the coming of Christ, but also the resources of Pentecost. So much more should be expected of the papacy than Old Testament kings, whose history is marked by greed, treachery, political intrigue and lust for power.

Third, as for the fact that some of the authors of the Bible committed serious sins, including murder, we should note that they repented of those sins. There is all the difference in the world between sinners who are sincere lovers of God who repent of their sins, and charlatans who show no evidence of genuine faith and love of God. Moses and David were both lovers of God whose sins should be viewed in light of the larger story of their lives.

Another objection might come from a different direction. It might be suggested that this argument proves too much. Given this argument, perhaps we should expect all clergymen to be persons of basic moral integrity and a sincere faith in Christ. While initially plausible, this is unrealistic, and indeed, the New Testament contains warnings that would hardly lead us to expect this. When Paul spoke to the Ephesian elders, he emphasized that part of their role as overseers, and shepherds of the church was to guard against false teachers. 'I know that after I leave, savage wolves will come in among you and will not spare the flock. Even from your own number men will arise and distort the truth in order to draw disciples after them' (Acts 20: 29-30). Given the reality of sin and imperfect human discernment, it is not surprising that ambitious and dubiously motivated persons should sometimes enter the ranks of the clergy, or that some would be corrupted. But it is another matter to think that the 'chief shepherd' who is uniquely chosen to lead the church, and who represents a providentially guaranteed 
succession beginning with Peter, should be as vulnerable and given to corruption as the history of the papacy shows it has been.

Now then, recall Duffy's observation, above, that popes have been 'appointed in a bewildering variety of ways'. Still, if all of these popes have been successors of Peter, if they are part of the unbroken chain of succession from Peter to the present, it is natural to assume they were all providentially chosen in some sense. Here it is worth emphasizing that more recently popes have been chosen in a more orderly fashion. Here is Duffy's account of some of the procedures in the election of popes.

In preparation for the enclave the cardinals are addressed by two preachers, chosen for their orthodoxy and wisdom, who reflect on the church's needs and the considerations which the cardinals should bear in mind in making their choice. The conclave begins with a solemn mass invoking the aid of the Holy Spirit in St Peters, and takes place within the Sistine Chapel within the Vatican palace itself, into which the cardinals process while a hymn to the Holy Spirit is sung (Duffy 2014: 452).

Duffy goes on to observe that for over 800 years, the normal method of choosing a pope is by secret ballot. The following is a description of a particularly significant part of the voting process.

Taking the folded form [the voting ballot] between thumb and index finger of the right hand, the cardinals then approach the altar of the Sistine Chapel in order of seniority, each one announcing in a clear voice 'I call as my witness Christ the Lord who will be my judge, that my vote is given to the one whom, before God, I think ought to be elected' (Duffy 2014: 453).

Given that the men who make this declaration are indeed outstanding men of God, and given their sincerity in their invocation of the aid of the Holy Spirit in the whole process, one should be inclined to have great confidence in the outcome and its providential direction.

Now let us consider a much more recent example that illustrates the problem I have been focusing on in this section. I refer to the pope who is in office as I write, namely, Pope Francis. The current pope has many admirers, to be sure, but he has also come increasingly under fire the past few years, especially from conservatives. The following lines come from an article by R. R. Reno, the editor of the conservative journal, First Things. The article is tellingly entitled 'A Failing Papacy'.

The current regime in Rome will damage the Catholic Church. Pope Francis combines laxity and ruthlessness. His style is casual and approachable; his church politics are cold and cunning. There are leading themes in this pontificate-mercy, accompaniment, peripheries, and so forth-but no theological 
framework... This has created a confusing, even dysfunctional atmosphere that will become intolerable, if it hasn't already...

The tendency of this pope is to undermine the Church's most loyal servants. This is surely galling. His lack of interest in theology-in ideas generallyreduces his pontificate to the raw exercise of ecclesiastical power...

Pope Francis seems to regard the uncertainty and instability as desirable...

I have the impression that the majority of the cardinals and other churchmen in positions of responsibility are increasingly aware the Francis pontificate is a failure (Reno 2019).

As scathing as this criticism is, it is not only fairly typical of the sort of criticism leveled against Francis, in some ways it is even mild, comparatively speaking.

In particular, Francis has been criticized for undermining traditional Roman Catholic theology in the controversial encyclical Amoris Laetitia. Many see that document as compromising Roman Catholic theology on divorce and remarriage, homosexuality and other moral issues. He has been sharply attacked for covering up the extensive sexual abuse in the ranks of the clergy, including bishops and cardinals, by an Archbishop, among many others. Indeed, some theologians and clergy have even gone so far as to accuse him of heresy (Weinandy 2019). And recently, his predecessor, Pope Bendict XVI issued a letter on sexual abuse that was perceived as a corrective to Francis (Harlan and Pitrelli 2019). All of this has contributed to the 'confusing, even dysfunctional atmosphere' that Reno laments in his article.

All of this poses an acute problem not only for 'cradle Catholics', but perhaps especially for Roman Catholic converts. Indeed, many converts have gone to Rome thinking that the Roman authority structure, headed by the pope, would provide security against the confusing conflict and divisions they encountered in Protestantism. And now the controversy and division surrounding Pope Francis may seem as bad, or even worse, than what they experienced as Protestants.

Jeff Mirus bluntly observes: 'A common question among Catholics today is: 'What was the Holy Spirit doing during the enclave that elected Jorge Bergoglio as Pope Francis?' (Mirus 2017). Mirus has an answer to that question as we shall see. In the next sections, we shall examine his answer, as well as another option Roman Catholics might embrace in response to this question.

\section{The Weaker Providence View}

I call this view the weaker providence view because it makes very few guarantees, and emphasizes the limits of God's control over papal selection. Mirus offers this response to the question he says many Catholics today are asking. 
The answer, of course, is that the Holy Spirit was doing what He is always doing, prompting all involved to cast their votes for the good of the Church, just as He has prompted all involved to form a proper understanding of the good of the Church. But the Holy Spirit does not choose the pope; that is left to the vagaries of men, and the vagaries of their response to grace.

In other words, the Holy Spirit does not arrange the votes so that the best possible candidate is elected... To put the matter succinctly, the promptings of the Holy Spirit are as certainly real as they are frequently resisted (Mirus 2017).

In a nod to the obvious corruption that has frequently marred the history of the papacy, Mirus acknowledges that the Holy Spirit does not prevent the electors of the pope 'from succumbing to other influences: Ignorance, falsehood, personal partiality, ill-conceived goals, and temptations of every kind, including those that are political and financial'.

Mirus does not cite any official documents in support of this view, so I don't know whether it is official Roman Catholic orthodoxy, but at the least, it is a popular view. Indeed, Pope Benedict affirmed a similar view when he was Cardinal Ratzinger. He said the following in 1997 when he was asked by a Bavarian television station whether the Holy Spirit chooses the pope.

I would not say so, in the sense that the Holy Spirit picks out the pope... I would say that the Spirit does not exactly take control of the affair, but rather, like a good educator, as it were, leaves us much space, much freedom, without entirely abandoning us. Thus, the Spirit's role should be understood in a much more elastic sense, not that he dictates the candidate for whom one must vote. Probably the only assurance he offers is that the thing cannot be totally ruined... There are too many contrary instances of popes the Holy Spirit obviously would not have picked! (cited by Martin 2013).

Ratzinger's final line here is telling. Any account of the how the Holy Spirit is involved in papal elections must come to terms with the actual history of the papacy.

The main strength of the weaker providence view is that it can more plausibly explain the many instances of popes the Holy Spirit obviously would not have chosen'. So long as the Holy Spirit does nothing more definitive than acting like a good educator who leaves much room for freedom; who prompts, but finally leaves the choice to the 'vagaries of men, and the vagaries of their response to grace', we should not be surprised if 'the best possible candidate' is not elected. Indeed, we may wonder if he is ever elected! In short, we have here a sort of 'free will theodicy' for the papacy. Perhaps we could even coin a phrase and call it a 'free will papodicy'. Bad popes and failing papacies are entirely due to the fact that papal elections are done by free agents, and they may follow the promptings of ignorance, 
partiality, and other temptations, rather than the prompting of the Holy Spirit.

While this appeal to free will may easily explain why the 'best possible candidate' is not always, if ever, chosen, it does not so easily explain why so many 'obviously' bad candidates have been chosen. Not a few of the popes have been so egregiously bad that it is hard to see how they could have been chosen without indicting the larger system that elected them. It would not take much spiritual discernment or even sincere faith in Christ and love for the church to see that openly immoral, transparently greedy and unscrupulous men should not have any sort of position of church leadership, let alone that of Supreme Pastor and Vicar of Christ.

The larger problem for this view is that it creates confusion and uncertainty about which popes should be trusted and followed. If there is no guarantee that the Holy Spirit providentially guides the selection of popes, how are faithful Roman Catholics to know who to believe? Some popes have been clearly good, and some have been obviously bad, at least with the advantage of historical hindsight. But some cases are much more ambiguous. Is there a clear criterion for sorting out the good and the bad popes? If there is, what is it? What is the advantage of having a Supreme pastor if he may not be God's choice, may set a grievously bad example by his own conduct, and may turn out to have led a failed papacy?

Consider again Pope Francis. Who should the faithful believe? The pope and his supporters or First Things magazine, Archbishop Vigano, and others who have labeled him a heretic? Should they look to Francis for guidance, or to cardinals who have openly criticized him? Or should they look to his predecessor? Consider Roman Catholic theologian Bryan Flanagan's observation about Pope Benedict's letter addressing sexual abuse: 'It's not good for the church to have two voices. If this is seen as Benedict attempting to give more context for his decisions, maybe this can be a helpful way to understand his mind-set. But this raises the specter of his voice being seen as an alternative to the papacy of Pope Francis. And that is bad for the unity of the church' (cited by Harlan and Pitrelli 2019).

When these sorts of questions are raised, Roman Catholics often respond by retreating to making very modest claims about the papacy. When they are making claims for the authority of the pope, and the vital nature of his office, and how his authority underwrites the claims of Rome to be the one true church, they make very exalted claims. Consider the following:

The Pope, Bishop of Rome and Peter's successor, 'is the perpetual and visible source and foundation of the unity both of the bishops and the whole company of the faithful'. 'For the Roman Pontiff, by reason of his office as Vicar of Christ, and as pastor of the entire Church, has full, supreme, and universal power over 
the whole Church, a power which he can always exercise unhindered' (Catechism of the Catholic Church 1995: paragraph 882).

But when we talk about historical reality and the numerous holders of the office who have made a mockery of these exalted claims, Roman Catholics remind us that there are actually very few guarantees with the papacy. Recall Pope Benedict's claim when he was still Cardinal Ratzinger: 'Probably the only assurance he offers is that the thing cannot be totally ruined.' To put it mildly, there is quite a stepdown from the exalted claims to the actual assurances. But notice also that Ratzinger's claim is quite general. He does not define more specifically what would count as the papacy being 'totally ruined'. Having scoundrels appointed pope who make a mockery of the office apparently does not totally ruin it. Having two or even three competing popes, and generating enormous controversy and confusion all across the church over who is the actual pope does not totally ruin it.

Indeed, when we press for specifics, perhaps the only guarantee is that the pope will not err when he speaks ex cathedra about morals or doctrine. Consider this official account of infallibility in light of our previous discussion. After stating that infallibility extends only as far as divine revelation, we read the following.

This is the infallibility which the Roman Pontiff, the head of the college of bishops, enjoys in virtue of his office, when, as the supreme shepherd and teacher of the faithful, who confirms his brethren in their faith (cf Luke 22:32), he proclaims by a definitive act some doctrine of faith or morals. Therefore, his definitions, of themselves, and not from the consent of the Church, are justly styled irreformable, for they are pronounced with the assistance of the Holy Spirit, an assistance promised to him in blessed Peter (cited by Flint 1998: 181-182).

Now this raises obvious questions. How is this 'assistance of the Holy Spirit' different from the assistance of the Holy Spirit in papal elections? If the promptings of the Holy Spirit may be ignored and resisted in favor of more carnal consideration in papal elections, then why cannot the assistance of the Holy Spirit be ignored or resisted in ex cathedra proclamations? Does God override freedom to preserve infallibility if necessary? If so, then why not do so in the case of disastrous papal elections? After all, cannot bad popes lead their followers into serious doctrinal error and moral confusion even if they are preserved from error in ex cathedra pronouncements?

\section{The Stronger Providence View}

These questions, at least some of them, have been given an ingenious answer by Thomas Flint, who appeals to Molinism to resolve them. In short, 
Flint's aim is to explain how papal infallibility is perfectly compatible with papal freedom.

Molinism, of course, is named after the sixteenth century philosopher Luis de Molina, whose famous theory of providence hinges crucially on the idea of 'middle knowledge'. Middle knowledge, roughly speaking is God's knowledge of what all possible persons would freely do in all possible circumstances and states of affair. The knowledge applies not only to actual persons, but also to persons who will never exist, and to circumstances and states of affairs that will never actually exist. For instance, suppose I had followed Alexander VI's example, and had numerous children by numerous women. God knows, say, what my sixth son would have chosen for dinner for his eighteenth birthday. More interestingly, he also knows what he would have done with respect to all the morally significant choices he would have made. Molina's basic theory is that God providentially governs the world by drawing on his middle knowledge and creating people in circumstances in which they will freely choose as he prefers.

Before giving us his Molinist solution it is worth noting that Flint acknowledges another way to maintain both papal freedom and infallibility, namely, by affirming the compatibilist account of human freedom, according to which freedom and determinism are compatible. If one affirms compatibilism, one can preserve infallibility by saying God determines and completely controls what the pope will pronounce ex cathedra, and thereby preserves it from error.

Flint wants to preserve a stronger libertarian account of freedom, however, and he thinks Molinism points the way. The essence of his proposal is captured in the following lengthy quote.

It is here the concept of middle knowledge seems to come to the rescue. For if God has middle knowledge, why can't he arrange things in such a way that the pope always freely follows his guidance? How, one might ask, can he do so? By seeing to it that the right person becomes pope. If God has middle knowledge, then he knows how any candidate for the office would act-would freely act-if elected pope. Using this knowledge, God would then direct the cardinals to select as pope one of those men who God knows would freely cooperate with his guidance and thereby safeguard the church from error; he would also lead them away from selecting any of those men who he knows would not freely cooperate with his guidance and consequently lead the church into error. By then guiding the man selected in the ways that, as his middle knowledge tells him, will elicit a free but positive response from him, God can insure that the pope is infallible even though he respects his freedom. This respect for human freedom would presumably extend to the cardinals as well. God's direction of them toward certain candidates and away from others would most likely be accomplished, not by God's determining their actions, but by his arrangement of circumstances which 
he knows via middle knowledge will lead to the result he desires (Flint 1998: 184-185).

Flint gives us a concrete example to make all this more concrete. Suppose, he says, that the two leading papal candidates are Cardinal Elfreth and Cardinal Filbert. Moreover, suppose the vote will be heavily influenced by the support of the elderly and highly respected Cardinal Rotundo. Finally, suppose that God knows by way of middle knowledge the following two propositions.

If Elfreth were elected pope at time $t$ in a world with history $h$, he would freely follow divine guidance and keep the church safe from error.

If Filbert were elected pope at time $t$ in a world with history $h$, he would freely reject divine guidance and proclaim ex cathedra a falsehood (Flint 1998: 185).

The story proceeds as follows. While Rotundo is praying and seeking the guidance of the Holy Spirit, God causes him to dwell on the many virtues of Elfreth. This causes him, as God knew by middle knowledge would surely happen, to come freely to the settled conclusion that Elfreth would make the better pope. 'Acting on this conviction, Rotundo enthusiastically throws his considerable weight behind Elfreth. As a result, Elfreth is indeed elected and the Church is saved from the errors that Filbert would have proclaimed' (Flint 1998: 185).

The whole idea of middle knowledge is deeply controversial, of course, but has been ably defended by Flint, and other proponents of Molinism. For our purposes, let us assume middle knowledge is possible and Molinism is a coherent account of providence. My concern is to assess whether Molinism provides help with the problem of bad popes.

In the first place, I am inclined to think Molinism does indeed provide a persuasive account of how popes could be fully free in the libertarian sense, and yet infallible in the restricted way Roman Catholic theology teaches. The scenario Flint describes for us clearly shows how this could happen. Matters are perhaps simplified by the fact that clear cases of the pope speaking ex cathedra are relatively rare. The two most famous cases that clearly qualify are the proclamations of the dogmas of Mary's immaculate conception and bodily assumption. Of course, the doctrine of infallibility assumes these doctrines are true, a claim that is itself controversial. Most Protestants reject these dogmas, and the Orthodox Church denies the immaculate conception, at least as Rome teaches it. So, for many Christians, the doctrine of papal infallibility has in fact been shown to be false by these two times the pope has spoken ex cathedra. But leaving that aside, Flint's Molinist scenario shows how, in principle, infallibility is compatible with libertarian freedom, and the one clear guarantee of papal theology could be true. 
However, while Molinism shows, in principle, how infallibility is compatible libertarian freedom, it may raise more questions than it answers. In particular, we might be more than a little curious to know how the Molinist accounts for the bad popes. Recall the heart of Flint's answer to the question of how God can use his middle knowledge to arrange things so the pope always freely follows his guidance and avoids error: 'By seeing to it that the right person becomes pope.' Moreover, he applies the same essential claims to the cardinals who select the pope. 'God's direction of them toward certain candidates and away from others would most likely be accomplished, not by God's determining their actions, but by his arrangement of circumstances which he knows via middle knowledge will lead to the result he desires' (Flint 1998: 185).

So here is the question clamoring for an answer: are we to believe that all the popes, including the notoriously bad ones, were the right person to become pope? Did God arrange things through his middle knowledge and providential direction so that each of these men would be appointed pope through the free choices of those who chose them? Is Ratzinger mistaken in thinking it obvious that the Holy Spirit would not have chosen some of the popes who have been picked? Or have all the popes in fact been picked by the Holy Spirit, in something like the way Elfreth was picked in Flint's scenario, contrary to what we might think?

An ingenious Molinist is not without possible replies. One possible move he might make is to suggest that there unfortunately were no better candidates available to be selected pope when the various bad popes were chosen. Reminiscent again of the theodicy parallel, perhaps God was faced with a situation of 'trans-papal depravity' in which all the viable candidates for pope were depraved, and the one chosen was actually the best one available at the time. So, when Octavian was made Pope John XII at the age of eighteen, for instance, there was simply no better choice at the time for the papal office. I must say I find this suggestion wildly implausible. Surely out of all possible candidates there were better choices to be made. However, we must concede to the determined Molinist that it is at least possible that no better choice was to be had, however improbable that may seem.

Another variation on this suggestion, inspired once again by the theodicy literature, is to suggest that we are simply not in any position to judge what providential reasons God may have for picking some of the popes he has. The theodicy parallel is 'skeptical theism', the view that finite human beings cannot possibly understand the reasons God may have for permitting the terrible evils that he does. There may be goods we cannot conceive, and connections between terrible evils and these goods that we cannot begin to fathom. Similarly, the 'skeptical papist' may say that there may be providential purposes for choosing the bad popes that we cannot begin to 
imagine or understand. While there may have been any number of papal candidates who were spiritually and morally much more suited to the papacy than Roderigo Borgia was, God may have had reasons entirely beyond our comprehension for arranging things so that he was elected Pope Alexander VI.

Once again, I find this suggestion highly implausible, even though it may still be possible in the strict sense of the word. It is worth noting, however, that Protestants might find it plausible for their own reasons. More specifically, Protestants might think the bad popes play the providential role of exposing the falsity of Roman papal theology. The numerous bad popes are a vivid demonstration that the pope is not the Vicar of Christ, or the Supreme Pastor of the Church. These popes demonstrate just how hollow are the claims of Vatican I, such as this one, cited above: 'For this reason it has always been necessary for every Church-that is to say the faithful throughout the word-to be in agreement with the Roman Church because of its more effective leadership.' Indeed, perhaps the providential purpose of the bad popes was to inspire the Protestant Reformation.

\section{Conclusion}

I conclude that the argument from 'conspicuous corruption' has considerable force, and the problem of bad popes is a serious one for Roman Catholicism. While there are possible moves to make to mitigate the problem, I find them rather implausible, whether of the weaker or stronger providence view.

Indeed, I judge the reality of bad popes and the numerous instances of conspicuous corruption to be better explained on the assumption that the Roman view of the papacy is human, all too human in its ultimate origins. The papacy, marred as it has often been by greed, violence and the quest for power and pleasure is perfectly explicable in terms of merely human, even sinful, desires and aspirations. Given this reality, the actual history of the papacy is only to be expected, but it is far from what we should expect if the papacy is indeed a divine institution ordained by God to play the vitally important role Roman Catholics claim it does. All in all, this evidence provides another reason to reject the claims of Rome.

\section{Bibliography}

*** (1995) Catechism of the Catholic Church, 2nd edition. New York, NY: Doubleday.

Collins KJ and Walls JL (2017) Roman but Not Catholic: What Remains at Stake 500 Years after the Reformation. Grand Rapids: Baker Academic. 
Duffy E (2014) Saints and Sinners: A History of the Popes, fourth edition. New Haven: Yale University Press.

First Vatican Council (1869-1870). Available for reading at: https://www.ewtn.com/catholicism/libra-ry/first-vatican-council-1505.

Flint T (1998) Divine Providence: The Molinist Account. Ithaca: Cornell University Press.

Harlan C and Pitrelli S (2019) Ex-Pope Benedict contradicts Pope Francis in unusual intervention on sexual abuse. Available for online reading at: http://www.washingtonpost.-com/world/speaking-out-at-this-difficulthour-a-once-quiet-ex-pope-pens-a-lengthy-letter-on-sexualabuse/2019/04/11/0ffa 162e-5c1a-11e9-a00e050dc7b82693_story.html?utm_term $=.8 \mathrm{ba072691 \textrm {ab } 0}$

Martin J (2013) Does the Holy Spirit Choose the Pope? Available for online reading at http://ideas.-time.com/2013/03/11/does-the-holy-spirit-choosethe-pope/.

Mirus J (2017) On the role of the Holy Spirit in papal elections. Available online at https://www.catholicculture.org/commentary/otc.cfm?id=1454.

Reno RR (2019) A Failing Papacy. Available at: https://www.firstthings.com/article/2019/02/a-failing-papacy.

Weinandy T (2019) Is Pope Francis a Heretic? Available for online reading at: https://www.firstthings.-com/web-exclusives/2019/05/is-pope-francis-aheretic. 